\title{
The Relationship Between Leisure Reading Habits, Vocabulary and Writing of English Language Learners (ELLs)
}

\author{
Jocelyn Yee Vun LEE \\ University of Technology Mara, Sabah, Malaysia \\ Alice Su Chu WONG \\ University of Technology Mara, Sabah, Malaysia
}

\begin{abstract}
Numerous studies have highlighted the influence of leisure reading habits on second language proficiency. The present study investigates the relationship between students' reading habits, vocabulary and writing performance. A reading survey, productive vocabulary test and writing test were administered to 33 university English language learners (ELLs) students in Malaysia. The results indicate that participants had not received a lot of support for reading from their English teachers at elementary schools or at secondary level and had limited access to reading resources. The university students in the study were aware of the value of reading in English, albeit spending a considerable amount of time on the Internet compared to reading off-line. More than half of the participants agreed that they would read something if it was recommended by their lecturers. In addition, the present study also found that participants had not acquired the adequate vocabulary size required for tertiary studies. The findings have important implications for English language practitioners both at school and tertiary levels.
\end{abstract}

Keywords: leisure reading habits, vocabulary size, second language writing, vocabulary development, second language reading

For decades, the reading habits of students are said to have had a strong influence on their language learning. A sizeable number of studies have attested that reading plays a significant role in second language acquisition (Elgort \& Warren, 2014; Elley \& Mangubhai, 1983; Grabe, 2008; Ito, 2011). Research in reading habits and writing in the first language (L1) has mostly treated as two separate, independent fields of study (Clark \& Foster, 2005; Hopper, 2005; Parodi, 2007; Shanahan, 2006). Most studies find that reading and writing are related (e.g., Jenkins, Johnson \& Hileman, 2004; Berninger, Abbott, Abbott, Graham, \& Richards, 2002; Loban, 1963; Maula, 2015). Like in the L1 setting, studies in reading habits and writing in the second language (L2) settings were mostly conducted separately (e.g. Erdem, 2015; Florence, Adesola, Alaba, \& Adewumi 2017; Iftanti, 2012). Little data exists on the links between the reading habits of university students and their writing and most of the studies concentrate

Language Education in Asia, 2017, 8(2), 157-175. http://dx.doi.org/10.5746/LEiA/17/V8/I2/A03/Lee_Wong 
almost entirely on primary and secondary students (Douglas \& Miller, 2016). We were disappointed by the scarcity of published research studies that address the impact of reading habits on the writing performance of university students.

The study reported in this paper was conducted in the English language learners (ELLs) context in Malaysia. It aimed at investigating whether university students' reading habits are related to their vocabulary and writing production at the start of their university studies. This paper begins with a definition of leisure reading, followed by an overview of reading habits in Malaysia. Reading and writing relationships are also discussed. It continues to describe the methodological tenets used in collecting data. The paper then presents the findings and discusses the implications in ELL language education.

\section{Leisure Reading as a Habit}

\section{Literature Review}

When reading act is done repeatedly, it becomes a habit. This habit is measured by the amount of materials being read, the frequency of reading and the amount of time spent on reading (Wagner, 2002). The International Reading Association or IRA, defines leisure reading as "independent, self-selected reading of a continuous text for a wide range of personal and social purposes." It is the reading students choose to do on their own. Leisure reading is often referred to as recreational reading, pleasure reading, free voluntary reading, spare time reading and independent reading. It takes place anytime in and outside of school.

Readers may read a wide range of texts including fiction, nonfiction, magazines and newspapers. Leisure reading is generally intrinsically or socially motivated and a pleasurable activity for the reader (Leisure Reading, 2014).

\section{Reading Habits in Malaysia}

Students' reading habits are by and large shaped by their home and school environments (Chin, Lee, \& Thayalan, 2007; Dijk, 2015; Kennedy \& Trong, 2010), and their writing production is determined by their vocabulary size. We draw on the sociocultural perspectives on literacy. Sociocultural theories related to literacy focus on ways people practice literacy in which they exist (Perry, 2012). Viewing literacy as a diverse set of contextualized practices helps researchers and practitioners understand the types of knowledge the learners use literacy which extend beyond their classroom learning.

Many of the studies conducted in Malaysia have reported that matriculation and university students spend very little time on leisure reading in the traditional sense. These students, who have undergone Malay medium instruction and have learned English as a single subject in schools preferred reading in Malay rather than in English (see Pandian \& Ibrahim, 1997; Shameen, 2016; Subashini \& Balakrishnan, 2013). Similarly, Malaysian Chinese students who learned English as a subject and graduated from Chinese secondary schools, tended to read Chinese materials rather than materials in English or Malay (Abidin, Pour-Mohammadi \& Ooi, 2011). Most of these students, labelled as reluctant readers (Pandian, 2000), have low interest in reading. A study by Chin, Lee, Thayalan (2007) found that students may be interested in 
reading, but they have not acquired reading as a habit, and this is consistent with Mohd Ariffin's (2010) findings.

Like many countries, access to new forms of media is becoming widespread in Malaysia. In a recent study, it is reported that Malaysian undergraduates spend more than 6 hours online using social media technologies (Lim, Agostinho, Harper, \& Chicharo, 2014). In a report from the Pew Research Centre, 70 per cent of users logged into Facebook at least once a day, and about 45 per cent logged into the site several times a day (Duggan, Ellison, Lampe, Lehnhart, \& Madden, 2015). In the present study, we identified some popular social network platforms on mobile and web applications namely Facebook, Twitter, YouTube, Whatsapp, Instagram, WeChat, and Google Plus.

The impact of digital media on students' learning engagement has been the subject of study by researchers from different disciplines such as psychology, computer science, education, literacy studies, and library and information science. With the accessibility of digital information and the increasing amount of time people spend reading electronic media, the digital environment has begun to affect people's reading habits (see Chen \& Yan, 2016; Chou, 2001; Junco, 2011; Lenhart, Purcell, Smith, \& Zickuhr, 2010; Rosen, Carrier, \& Cheever, 2013). Electronic media use among university students has a profound impact on students' reading. Today's young adults are more digital active than any previous generation as reported by Pew Research Centre (Zickuhr \& Smoth, 2012). Reading on digital devices or online reading can be considered as a form of reading. The underlying question is whether students engage deeply with a digital text in the same way they do when reading a printed text. Other studies such as Liu (2005) and Picton (2014) found that the habits in reading on screen or screen-based reading has been the most common habit for young people. Students who prefer screen-based reading often spend more time browsing and scanning, keyword searching, reading selectively and spend little time on in-depth reading. Attention span while reading is also shorter. Although annotating and highlighting is common in print reading, it has not yet "migrated" to the digital environment when people read electronic texts (Liu 2005, p. 707).

A study on scholars as the student subjects by Nicholas, Huntington, Jamali, Rowlands, Dobrowski, and Tenopir (2008) found that there is a large proportion of full-text reading on screen. This shows an increasing screen-based reading habits of late due to the relatively more time spent reading electronic documents (Liu, 2005). Some studies report that students rather view than read and do not possess the critical and analytical skills to retrieve the information found on the Internet (see e.g., Rowlands et al. 2008). In the present study, we did not explore the state of e-book reading i.e., long-form writing in digital format when participants were in primary and secondary schools. This is because most of these students were from suburban and rural regions where there is limited or no access to the Internet. Computers at schools are also not readily available as school computer laboratories are restricted to teaching technology rather than for accessing internet resources (Abidin, Pourmohammadi, Varasingam \& Ooi, 2014). Also, mobile phones and ipads are prohibited at schools. Although in the present study students' exposure to social media was not the main focus, their reading habits were shaped by the social and cultural contexts where they were situated. 


\section{Reading and Writing Relationships}

Research traditionally approached writing and reading as distinct areas of exploration (Langer \& Flihan, 2000). Only in the 1960s, spearheaded by the Center for Cognitive Studies at Harvard, were writing and reading regarded as related language processes. In his seminal paper, Loban (1963) reported strong relationships between reading and writing i.e., students who wrote well also read well, and that the converse was true. Since then, such relationships have become more widely recognized (Harl, 2013). Stotsky (1983) investigated reading and writing relationships through her much cited synthesis which spans approximately fifty years from the beginning of the 1930s to 1981. She claimed that "better writers tend to be better readers", "better writers tend to read more than poorer writers", and that better readers tend to produce more syntactically mature writing than poorer readers" (p. 636). In other words, reading experience appears to be a consistent correlate of, or influence on, students' writing ability. In a similar vein, Pearson (2002) refers to the relationship between reading and writing as synergistic. Parodi's empirical study (2007) further showed significant coefficients between reading and writing of argumentative texts. However, these studies on reading and writing relationships were all conducted in the L1 contexts.

In second language (L2) learning, prominent scholars in vocabulary studies (Goulden, Nation \& Read, 1990; Laufer \& Goldstein, 2004) claim that one of the key predictors is lexical competence. Studies on the relationship between vocabulary size and the skills of reading, writing and listening have suggested that vocabulary knowledge is a strong predictor of general proficiency in a foreign language. This is especially evident as far as L2 writing is concerned. Studies on relationships between vocabulary and L2 writing have found that as L2 vocabulary size increases, so does the ability to write more effective texts (Cumming, 1989). In fact, numerous studies have highlighted the role of L2 proficiency in L2 writing ability and L2 writing fluency (Sasaki, 2000; Yun, 2005, Tseng \& Schmitt, 2008; Wong, 2012). The general consensus is that the restricted vocabulary of L2 learners limits their writing quality and fluency. This realization has further strengthened the theory that vocabulary knowledge is central to the development of L2 writing (Ashrafzadeh \& Nimehchisalem, 2015; Lee, 2014; Wong, 2012). As emphasized by Milton (2010, p.58), "current thinking advocates that vocabulary may be crucial to the development of language performance overall". Hence, the current enquiry on the role of vocabulary size in writing is deemed fitting in the current Malaysian academic setting.

Despite increased attention in the L2 or ELL context, the empirical evidence for the relationship of reading habits and writing in a second language is largely unexplored. A majority of studies have been either on the reading habits (see Abidin, Pour-Mohammadi, \& Ooi, 2011; Pandian \& Ibrahim, 1997; Shameen, 2016; Subashini \& Balakrishnan, 2013) or the writing performance of ELLs (Chow, 2007; Maarof, Yamat, \& Li, 2011; Wong 2005). It is not altogether clear whether ELLs' reading habits are integral to their writing performance. To address these gaps in the previous research, we designed our studies to involve first year university students in a reading survey, a productive vocabulary test and a writing task with no direct instruction from the lecturers. Thus the current investigation took the form of a correlation study to determine whether students' reading habits prior to and at university entrance correlate with their vocabulary size and writing. 


\section{Method}

\section{Design}

The study was primarily quantitative in nature as it attempted to explore the reading habits of ELL university students and the relationship between the variables in the study. The independent variable was participants' reading habits and the dependent variables were their vocabulary size and writing performance. Two sessions were set aside for data collection: the vocabulary test was the first to be administered, while the reading survey and the writing task were conducted on the same day.

\section{Research Questions}

This study addressed the following research questions:

1. What are the English reading habits of ELL first year university students in Malaysia?

2. What is the English vocabulary knowledge of ELL first year university students in Malaysia?

3. What is the relationship between ELL first year university students' English reading habits and their writing performance?

4. What is the relationship between ELL university students' English vocabulary knowledge and their English writing performance?

5. What is the relationship between ELL students' English reading habits and their English vocabulary knowledge?

\section{Participants}

The present work used a convenience sample of 33 ELL university students majoring in different fields of study. Participants were in their first-year university programme and were taught by one of the researchers in this study. Although initially 47 students took part in the data collection, 14 were absent during the second session and had to be excluded from the study. The participants were all indigenous students whose age ranged from 19 to 22 . English was not their first language but all of them had learnt the target language for more than 12 years before enrolling in the university. The participants' level of English ranged from low to intermediate and they were all taking English as a prerequisite subject in their course programme. The low level is equivalent to A2 Level which is a Basic User in Common European Framework of Reference for Languages (CEFR) and the intermediate level is equivalent to B2 Level which is an Independent User in CEFR. Most participants were staying in student dormitory where a television room was not provided. Although there was wi-fi on campus, the connection was often disrupted unless they were in hotspots. Most students had their own Internet connection, but they rarely watched movies or Youtube online unless they had free access to the Internet. The university library was at a distance from their hostels.

\section{Data Collection and Instrument}

ELL learners' vocabulary size, written skills and reading habits were assessed by administering a productive vocabulary level test (PVLT), a writing test and a reading habit questionnaire.

Productive Vocabulary Level Test (PVLT). Although there are three main productive vocabulary tests in the literature: Lexical Frequency Profile (LFP; Laufer \& Nation, 1995), PVLT; Laufer \& Nation, 1999) and the Lex30 (Meara \& Fitzpatrick, 2000), the PVLT (Laufer \& Nation, 1999) 
was chosen as it is a reliable, valid and practical measure of vocabulary growth. The PVLT is intended to assess controlled productive vocabulary, in contrast to receptive vocabulary as measured by the VLT. The PVLT measures students' productive knowledge in a limited context i.e., fill-in task where a sentence context was provided and students had to provide the missing word. The test comprised five sections; 2000 level, 3000 level, 5000 level, academic word level and 10000 level. The maximum possible score for each section was 18 and participants were given 45 minutes to complete the test.

Reading Behaviour Questionnaire. A reading behaviour questionnaire was used to elicit information on participants' reading habits. The questionnaire consisted of four sections; Sections A, B C and D. Section A (Home Variables) consisted of 9 items which elicited information regarding participants reading habits at home. This includes the frequency of reading English materials at home and possession of English reading materials at home. Section B (School Variable) consisted of 9 items which elicited information regarding reading habits at school. This includes involvement in reading activity in English, teachers' encouragement to read English materials in school and library assignments in English. Section C (Behaviour, Attitudes, Opinion towards Reading) consisted of 13 items which elicited information regarding participants' overall perception and attitude on reading. Section D (Demographic) consisted of 4 items which elicited information regarding participants' background. All items were presented in English and Malay. Participants were given 20 minutes to complete the questionnaire.

Writing Task. A writing task consisting of writing an expository essay on the topic "Mobile devices can be effective learning tools for university students. Do you agree with this statement?" was administered in the study. This topic was deemed appropriate as it was something that university students could relate to. Participants were given 40 minutes to complete the task which required them to provide points relevant to the topic. The reading behaviour and the writing task were conducted on the same day.

\section{Evaluation of Students' Writing}

Students' writing was evaluated based on the Essay Writing Score Guide which was adapted from ESL Composition Profile (Jacobs, Zinkgraf, Wormuth, Hartfiel, \& Hughey, 1981, p.30). This analytic rating scale was chosen as it is one of the most widely used and recognizable rubrics in second language writing (Brooks, 2013). Additionally, the ESL Composition Profile has been recognized to have a high degree of both internal and external validity (Bacha, 2001). For this reason, many researchers have utilised the profile to measure second language writing performance (Ito, 2011; Mukundan, Mahvelati, Mohd Amin Din \& Nimehchisalem, 2013; Reimer, 2013; Zare-ee, Hematiyan \& Matin, 2012). The original Profile consists of five main component scales - Content, Organisation, Vocabulary, Language Use and Mechanics. For the purpose of this study, only three of these components were measured: Content, Vocabulary and Language Use.

Data Analysis Method. Two main statistical analyses were employed in the present study. First, descriptive statistics were calculated on the responses to the scaled questions in the questionnaire. Frequency distribution was carried out to describe participants' reading habits, 
level of vocabulary and writing performance. Following this, inferential statistics were carried out using a correlation analysis. The Pearson Product-Moments correlation test, which is a parametric test, was used in the present study to examine the relationships between the PVLT, reading habits and writing performance. Meanwhile, the responses to the open-ended questions were coded and then categorized according to themes developed through the analysis.

\section{Results}

In Section A of the questionnaire, students were asked to indicate the types of reading materials they have at home and their exposure to reading English materials. Findings showed that $80 \%$ $(\mathrm{N}=26)$ of participants said that they did not have any English reading materials at home. However, over 50\% ( $N=18)$ said they had English comics, while about $70 \%(\mathrm{~N}=22)$ said they had English newspapers at home. With regard to exposure to reading English materials at home, it was discovered that $58 \%$ of the participants reported having had their parents read to them in English. However, the findings do not show the age at which parents stopped reading to them. Only $38 \%$ of students received books as presents and a lower number of students (18\%) had parents/siblings reading English materials.

In terms of access to English reading material available at home, it was found that over half of the participants in this study possessed not more than ten English reading materials at home. For this question, students were asked to indicate the number of English reading materials at home specifically English books, English magazines and English comics as opposed to the first question which only indicated English reading materials in general. Findings also indicate that a majority of students (58\%) reported not having any English newspapers at home, 24\% reported having only one to two newspapers per week and only $9 \%$ reported having seven or more newspapers in a week. Additionally, most students (91\%) reported that they have never purchased any e-books.

Section B of the questionnaire asked students about the type of support in reading they received in school. The support here included provision of supplementary reading materials in school, library assignments and encouragement from teachers. As seen in Table 1, 85\% of the respondents and $93 \%$ of the respondents did not receive any supplementary reading materials in primary school and secondary school respectively. These percentiles inform us that other than the textbooks prescribed by the schools, there were no other reading materials given by teachers. This includes work that required library research: about $80 \%$ claimed that they did not need to go to the library to do their homework. Over $94 \%$ reported not receiving any encouragement from primary school teachers to read for pleasure in English. Similarly, a collective $100 \%$ of students reported not receiving encouragement to read for pleasure in English while they were in secondary school. The data further indicate that only $9 \%$ of the students witnessed their teachers reading English materials in school. 
Table 1

Support and encouragement to read English materials in school

\begin{tabular}{lll}
\multicolumn{1}{c}{ Type of materials } & Yes & No \\
\hline Received supplementary English reading materials in primary school & $15 \%$ & $85 \%$ \\
Received supplementary English reading materials in secondary school & $3 \%$ & $93 \%$ \\
Were given library assignments in English & $21 \%$ & $79 \%$ \\
Encouragement from primary school teachers to read for pleasure & $6 \%$ & $94 \%$ \\
Encouragement from secondary school teachers to read for pleasure & 0 & $100 \%$ \\
Seen English teachers reading English materials & $9 \%$ & $91 \%$ \\
\hline
\end{tabular}

RQ 1: What are the English reading habits of ELL first year university students in Malaysia? Section $C$ of the questionnaire listed eight reading behaviour-related items for which students indicated their degree of agreement on a scale from 1 (strongly disagree) to 5 (strongly agree). The findings suggested that a majority of the respondents (over $50 \%$ ) agreed that reading is useful only for those who want to study and that reading is only for those who don't have a hobby. $75.8 \%$ agreed that reading is better than doing other activities. This may not necessarily mean that they would read; it could mean that they wish they read more. However, about $67 \%$ disagreed with the idea that reading is boring. Another interesting finding also suggests that most students would read something if it was recommended by the lecturer.

Table 2

Habits towards reading

\begin{tabular}{|c|c|c|c|c|c|}
\hline & $\begin{array}{l}\text { Strongly } \\
\text { disagree }\end{array}$ & Disagree & $\begin{array}{l}\text { Do not } \\
\text { know }\end{array}$ & Agree & $\begin{array}{l}\text { Strongly } \\
\text { agree }\end{array}$ \\
\hline $\begin{array}{l}\text { Reading materials are only for people who } \\
\text { don't have a hobby }\end{array}$ & 39.4 & 36.4 & 6.1 & 12.1 & 6.1 \\
\hline $\begin{array}{l}\text { Reading is useful only for those who want to } \\
\text { study }\end{array}$ & 24.2 & 18.2 & 3.0 & 12.1 & 42.4 \\
\hline Reading is better than doing other activities & 0 & 18.2 & 6.1 & 60.6 & 15.2 \\
\hline $\begin{array}{l}\text { I like surfing the Internet and prefer watching } \\
\text { TV/DVD to reading }\end{array}$ & 3.0 & 6.1 & 15.2 & 48.5 & 27.3 \\
\hline $\begin{array}{l}\text { I will read something if it is recommended by } \\
\text { my lecturer }\end{array}$ & 0 & 27.3 & 18.2 & 48.5 & 6.1 \\
\hline Reading is boring & 30.3 & 36.4 & 24.2 & 9.1 & 0 \\
\hline
\end{tabular}

With regard to students' activities after class, it was found that $45 \%$ of the students seldom read English books after class. As seen in Table 3,52\% of students said that they sometimes read a book in English. They spent most of their time (73\%) on social media and talking with friends $(67 \%)$, and $48.5 \%$ sometimes or often checked their email in English. Interestingly, few students watched television $(30 \%)$. 
Table 3

What students do after class

\begin{tabular}{lllll}
\hline & Never & Rarely & Sometimes & Often \\
\hline Read a book in English & 3 & 42.4 & 51.5 & 3 \\
Watch television & 42.4 & 27.3 & 12.1 & 18.2 \\
Do homework & 0 & 6.1 & 75.8 & 18.2 \\
Talk with friends & 0 & 12.1 & 21.2 & 66.7 \\
Engage in social media & 0 & 3.1 & 21.2 & 72.7 \\
Check email in English & 6.1 & 45.5 & 39.4 & 9.1 \\
\hline
\end{tabular}

RQ 2: What is the English vocabulary knowledge of ELL first year university students in Malaysia?

Descriptive statistics for the vocabulary measure is presented in Table 4. As can be seen, scores for 2000 level test ranged from 5 to 17, with a mean of 11 and a standard deviation of 3.39. For the 3000 level test, scores ranged from 2 to 15, with a mean of 9.3 and a standard deviation of 3.67. For the 5000 level test, scores ranged from 0 to 11, with a mean of 4.1 and a standard deviation of 3.32. For the academic level test, scores ranged from 0 to 11 with a mean of 6.0 and a standard deviation of 2.7. For the 10000 level test, scores ranged from 0 to 4.0 with a mean of 0.9 and a standard deviation of 1.2. These distributions suggest that the 2000 level vocabulary test was not difficult for the students given the relatively high mean scores and that some individuals achieved almost maximum possible scores. Results also suggest that the 3000 level, 5000 level and Academic level tests were difficult for the students given the low mean scores and the fact that some individuals scored 0 . The 10000 level test was the most difficult for the students given the relatively low mean scores and that the highest score was only 4.

\section{Table 4}

Vocabulary test scores of ELL students

\begin{tabular}{lccccc}
\hline & Minimum & Maximum & $\begin{array}{l}\text { Maximum } \\
\text { possible score }\end{array}$ & Mean & SD \\
\hline 2000 Level & 5.0 & 17 & 18 & 11 & 3.39 \\
3000 Level & 2.0 & 15 & 18 & 9.3 & 3.67 \\
5000 Level & .00 & 11 & 18 & 4.1 & 3.32 \\
Academic Level & .00 & 11 & 18 & 6.0 & 2.70 \\
10000 Level & .00 & 4.0 & 18 & .9 & 1.20 \\
\hline
\end{tabular}

RQ3: What is the relationship between ELL first year university students' English reading habits and their writing performance?

A correlational analysis was conducted to investigate the relationship between students' reading habits and writing performance. As presented in Table 5, no significant correlation was 
found between reading habits and content scores $(p=.851)$. Similarly, no significant correlations were found between reading habits and language scores $(p=.538)$ or between reading habits and vocabulary scores $(p=.621)$. Contrary to expectations, participants' reading habits were not associated with their writing performance. Table 5 also reports the relationship between writing performance and the frequency of loaning library books. The findings indicate positive correlations between language scores and the frequency of borrowing library books, $r$ $=.424^{*}, \mathrm{p}=.014$. There was also a positive relationship between vocabulary scores and the frequency of borrowing library books, $r=.384^{*}, p=.028$. However, no correlation was found between content scores and frequency of borrowing library books, $r=.166, p=.356$. Overall, the finding suggests that as the frequency of borrowing library books increases, so does the likelihood of students getting higher writing scores, particularly in language and vocabulary.

\section{Table 5}

Correlations among writing scores, reading habits and the frequency of borrowing books

\begin{tabular}{lll} 
& Borrow library books & Reading Habits \\
\hline Content & .166 & .034 \\
Language & $.424^{*}$ & .111 \\
Vocabulary & $.384^{*}$ & .089 \\
\hline
\end{tabular}

$$
\begin{aligned}
& \mathrm{N}=33 \\
& { }^{*} p<.05,{ }^{*} * p<.01
\end{aligned}
$$

RQ 4: What is the relationship between ELL university students' English vocabulary knowledge and their English writing performance?

Bivariate correlations between the vocabulary test and writing scores are presented in Table 6 . The overall findings indicate positive relationships between students' writing performance and vocabulary knowledge. As can be seen, there were significant correlations between language scores and 2000 level $\left(r=.497^{* *}\right)$ and between language scores and 5000 level $\left(r=.456^{* *}\right)$. Similarly, there were significant positive correlations between vocabulary scores in writing and the 2000 level $\left(r=.416^{*}\right)$ and vocabulary score and the 5000 level $\left(r=.421^{*}\right)$. Although the rest of the findings did not show significant correlations, the overall results show a trend towards a relationship between vocabulary size and writing performance.

\section{Table 6}

\section{Correlation between vocabulary test and writing scores}

\begin{tabular}{llcccc}
\hline & 2000 Level & 3000 Level & 5000 Level & $\begin{array}{c}\text { Academic } \\
\text { Level }\end{array}$ & 10000 Level \\
\hline Content & .282 & .164 & .314 & .100 & .205 \\
Language & $.497^{* *}$ & .278 & $.456^{* *}$ & .230 & .305 \\
Vocabulary & $.416^{*}$ & .258 & $.421^{*}$ & .144 & .272 \\
\hline
\end{tabular}


$\mathrm{N}=33$

$* p<.05,{ }^{* *} p<.01$

\section{RQ 5: What is the relationship between ELL students' English reading habits and their English vocabulary knowledge?}

Table 7 presents the relationships between vocabulary scores and habits towards reading. As can be seen, there is a significant correlation between reading habits and the 2000 level test, $r=.409^{*}, p=.018$. Additionally, results also showed that there is a significant correlation between reading habits and the 5000 level test, $r=.458^{* *}, p=.007$. The overall finding showed a trend towards a relationship between reading habits and vocabulary which suggests that as positive reading habits develop, so does vocabulary size. A bivariate correlation analysis was also carried out to explore the relationship between reading habits and interest in learning English. The finding indicates a significant correlation between the two variables, $r=.432^{*}, p=$ .012. This suggests that as interest in English develops, so do reading habits.

Table 7

\section{Correlation between vocabulary test and reading habits}

\begin{tabular}{|c|c|c|c|c|c|c|}
\hline & $\begin{array}{l}\text { Interest in } \\
\text { learning English }\end{array}$ & 2000 Level & 3000 Level & 5000 Level & $\begin{array}{l}\text { Academic } \\
\text { Level }\end{array}$ & 10000 Level \\
\hline $\begin{array}{l}\text { Reading } \\
\text { habits }\end{array}$ & $.432^{*}$ & $.409^{*}$ & .298 & $.458^{\star *}$ & .036 & .308 \\
\hline
\end{tabular}

$\mathrm{N}=33$
${ }^{*} p<.05, * * p<.01$

\section{Limitations and Future Research}

There are a number of limitations suggesting the results should be considered with caution. A major limitation was the inability to ensure all the students were present on the two days of data collection. As a consequence, the data collected from 33 participants may not be able to represent the reading habits of ELL university students. A replication of the same study with a larger sample size would provide more reliable and generalizable results. Another limitation was the divided views for some of the items in the reading behaviour section. Although some items yielded conclusive and interesting findings, some remained inconclusive. Hence, future studies could possibly include a qualitative measure to ascertain students' reading habits to yield more decisive responses. This data could then be triangulated with the quantitative data so that a more substantive conclusion regarding students' reading habit can be made. Another limitation of the present research was that students were not asked specifically what they did online. The inferences that we made about their engagement in social media was restricted to social interaction in a fun and entertaining way. Whether students use social media such as Facebook, Twitter or Whatsapp for information gathering was not clear, although the credibility of news available through social media is a source of concern. Future research that considers change over time in the platform in students' reading is planned. This may entail an 
investigation of students online reading habits, online activities, vocabulary size and how these variables correlate with each other.

\section{Discussion and Implications}

Based on students' performance on the PVLT, writing test and responses from the Reading Behaviour Questionnaire, four key findings emerged. Firstly, it was discovered that participants neither received a lot of support in terms of fostering reading in English from their teachers at elementary schools nor at secondary level. Areas of neglect include the lack of library assignments in school and encouragement to read for pleasure. Two-thirds of the participants believe that English benefits them, yet they do not see the connection between the importance of reading and language learning. This can be justified as only half of the participants read occasionally.

The second key finding relates to students' use of social networking sites. The present study confirms that millennial generations (adults between 18 and 29) have a high reliance on the Internet and social networking usage as previous studies have demonstrated (Chen \& Yan, 2016; Chou, 2001; Junco, 2011; Lenhart et al., 2010; Rosen et al., 2013). Although students like surfing the Internet and spend most hours online i.e., about $94 \%$ (see Tables $2 \& 3$ ), it is uncertain whether they engage in any form of deep reading. This form of reading which requires attention may be difficult for them as they tend to multitask with ICT (i.e., constant switching of phone/computer screens, where attention to content changes at a rapid rate). As Carrier, Cheeverb, Rosena, Beniteza \& Changa (2009) have argued, digital natives utilised various types of media at the same time. Additionally, it was noted that students have been reading on screen, but often times they are browsing and scanning (Liu, 2005; Picton, 2014). Despite the surge in popularity of e-books in other parts of the world, a majority of the participants in the present study had never purchased an e-book. Yet, they were active social media users. Although this seems to be a hindrance in the development of good reading habits, it can also be regarded as an opportunity to motivate students to read via a much-preferred platform. Digital natives may be more open to the idea of accessing reading assignments via social media platforms such as Edmodo, Schoology and even Facebook. Thus, educators in general need to be aware of this changing habit in reading and address it by accommodating students' preferred reading medium via popular social media platforms. This can be made possible by supplementing conventional reading classrooms with virtual reading classrooms which blend online learning and face to face discussion through Edmodo or Facebook. This method allows the extension of regular classroom reading assignments which students can access conveniently. For instance, a recommended text posted by the teacher can be read, downloaded and discussed electronically. Online discussion such as this is a value-added channel as it encourages students who are reticent to share their views in a non-threatening way.

The third key finding of the present study relates to students' level of vocabulary and its relation to students' reading habits. Firstly, it was discovered that participants have not acquired the necessary vocabulary size required for university studies. Among all the vocabulary measures, the 2000-word level was the least difficult for the students. Results further indicated that the 3000 level, 5000 level, 10000 level and the Academic level tests were difficult for the students. 
This vocabulary deficiency may prevent students from comprehending and writing academic text at the university level. This finding echoes that of Harji, Balakrishnan, Bhar and Letchumanan (2015) which revealed that undergraduates are not equipped with necessary vocabulary size for university studies. This is a great concern as a threshold level of vocabulary is needed for successful language learning. As mentioned in previous studies (Hsueh-Chao \& Nation, 2000; Morris \& Cobb, 2004; Waring \& Nation, 2004) vocabulary knowledge is a significant predictor of academic performance and a prerequisite for academic success especially where second language is concerned. In order to achieve success in language learning, a second language learner must at least acquire a lexical base of 3000-word level (Harji, Balakrishnan, Bhar \& Letchumanan, 2015).

Secondly, it was also found that positive reading habits were significantly correlated with students' vocabulary size. This implies that as positive reading habit develops, so does students' vocabulary size. Based on these salient findings, certain pedagogical implications can be made. For the most part, teachers should strive to encourage students to read English materials for pleasure. Given the fact that half of the participants agreed they would read something if it was recommended by their lecturers, the responsibility to encourage students to read may rest with the teacher. As mentioned previously, teachers should give extended reading assignments via virtual reading classroom to extend students' reading activities. In an age where digital technology is pervasive, it would seem appropriate for teachers to develop and improve students' digital literacy skills. Other than that, teachers should integrate the teaching of vocabulary with the teaching of reading comprehension strategies. This integration allows for multiple approaches to reading tasks and may cater to learners' of different L2 proficiency levels. According to Hunt and Beglar (2005), the most effective form of learning with regard to vocabulary instruction involves a careful blend of both explicit and implicit instruction and learning. As such, explicit instruction through decontextualized lexis for acquisition of new words and implicit lexical instruction through meaning-focused reading should be carried out in ELL traditional and virtual reading classrooms. Explicit teaching involves teaching a set of words that are related to students conceptually which may appear in texts that students have read or will be reading later. This is followed by providing students multiple exposures with the aim to deepen understanding in addition to giving opportunities to students to use and internalise the words in different contexts such as group discussions, individual activities or teacher-led groups. These exposures promote incidental vocabulary learning i.e., learning words as a by-product of reading, listening, discussing and writing. In short, the combination of vocabulary instruction in reading activities will give students the exposure to new lexicon as well as enhance students' reading skills such as paraphrasing and summarizing. Other than teaching words that students will be expected to read, selecting useful words from the academic word lists to build students' academic vocabulary will also benefit second language learners. Many of them are unlikely to encounter much academic language in their everyday lives. Therefore, developing activities for them to use academic language for interaction among themselves and with the teacher to accelerate their vocabulary is crucial for their academic achievement.

The fourth key finding of the present study affirms that there is a relationship between productive vocabulary size and writing performance, particularly for language and vocabulary 
scores. This finding is consistent with previous literature (Ashrafzadeh \& Nimehchisalem, 2015; Lee, 2014; Wong, 2012) which links vocabulary size to writing performance. Indeed, this further emphasizes the significant role of vocabulary as one of the strongest predictors of writing quality. Based on this discovery, a practical implication can be made. Similar to the integration of vocabulary in reading, lexical instruction should also be integrated in writing. While reading gives students exposure to vocabulary and syntax, writing activities give students practice in using them. According to Wong (2012), by emphasizing and integrating vocabulary in writing lessons, students will be more accustomed to thinking of vocabulary as part of the writing process. In this regard, teachers could apply explicit vocabulary instruction by demonstrating how newly learned words can be utilized in a production task and how lexical variation can affect writing quality. This form of scaffolding method may require teachers to model and demonstrate the use of vocabulary in writing activities, provide appropriate language prompts for writing task and pre-teach vocabulary in preparation for a task.

Overall, the combination of findings in the current work provides some support for the conceptual premise that vocabulary, reading and writing are interconnected. It is argued that the integration of these interrelated skills in classroom activities may lead to successful language acquisition. It is also argued that in line with the change in students' reading habit and their high reliance on Internet and the social network, social media platform should be used as instructional tools for expanded reading instruction and vocabulary acquisition. Despite its exploratory nature, this study offers some insights into the possible initiatives that English language teachers could implement to develop vocabulary acquisition, and good reading habits. 


\section{References}

Abidin, M. J. Z., Pour-Mohammadi, M., \& Ooi, C. L. (2011). The reading habits of Malaysian Chinese university students. Journal of Studies in Education, 1(1), 1-13. doi: http://dx.doi.org/10.5296/jse.v1i1.1037

Abidin, M. J. Z., Pourmohammadi, M., Varasingam, N., \& Ooi, C. L. (2014). The online reading habits of Malaysian students. The Reading Matrix, 14(2), 164-172. Retrieved from http://www.readingmatrix.com/files/11-t91466a8.pdf

Ashrafzadeh, A., \& Nimehchisalem, V. (2015). Vocabulary knowledge: Malaysian tertiary level learners' major problem in summary writing. Journal of Language Teaching and Research, 6(2), 286-291. doi: http://dx.doi.org/10.17507/jltr.0602.07

Bacha, N. (2001). Writing evaluation: what can analytic versus holistic essay scoring tell us? System, 29(3), 371-383. doi: http://dx.doi.org/10.1016/S0346-251X(01)00025-2

Brooks, G. (2013). Assessment and academic writing: A look at the use of rubrics in the second language writing classroom. Kwansei Gakuin University Humanities Review, 17, 227-240. Retrieved from https://kwansei.repo.nii.ac.jp/?action=repository_action_common_download\&item_id= 22918\&item_no=1\&attribute_id $=22 \&$ file_no $=1$.

Berninger, V. W., Abbott, R. D., Abbott, S. P, Graham, S., \& Richards, T. (2002). Writing and reading: Connections between language by hand and language by eye. Journal of Learning Disabilitie.. Special Issue: The Language of Written Language. 35(1), 39-56. doi: http://dx.doi.org/10.1177/002221940203500104

Carrier, L., Cheeverb, N., Rosena, L., Beniteza, S., \& Changa, J. (2009). Multitasking across generations: Multitasking choices and difficulty ratings in three generations of Americans. Computers in Human Behavior, 25(2), 483-489. Retrieved from http://dx.doi.org/10.1016/j.chb.2008.10.012

Chen, Q., \& Yan, Z. (2016). Does multitasking in mobile phones affect learning? A review. Computer in Human Habits, 54, 34-42. Retrieved from http://dx.doi.org/10.1016/j.chb.2015.07.047

Chin, D., Lee, J. Y. V., \& Thayalan, X. (2007). Reading habits and the influence of reading on the English Language proficiency among students at UiTM Sabah. Retrieved from http://eprints.ptar.uitm.edu.my/4360/

Chou, C. (2001). Internet heavy use and addiction among Taiwanese college students: An online interview study. Cyber Psychology and Habits, 4(5), 573-585. doi: http://dx.doi.org/10.1089/109493101753235160

Chow, T. V. F. (2007). The effects of the process-genre approach to writing instruction on the expository essays of ESL students in a Malaysian secondary school. PhD diss., Universiti Sains Malaysia, Penang, Malaysia.

Clark, C., \& Foster, A. (2005). Children's and young people's reading habits and preferences: The who, what, why, where and when. England, UK: National Literacy Trust. Retrieved from https://files.eric.ed.gov/fulltext/ED541603.pdf

Cumming, A. E., (1989). Writing expertise and second language proficiency. Language learning, 39(1), 81-135. doi: http://dx.doi.org/10.1111/j.1467-1770.1989.tb00592.x

Dijk, M. V. (2015). The influence of reading motivation on reading habits. A qualitative study on the reading habits of high school students. (Master thesis). Retrieved from https://dspace.library.uu.nl/handle/1874/320007 
Douglas, Y., \& Miller, S. (2016). Syntactic and lexical complexity of reading correlates with complexity of writing in adults. International Journal of Business Administration, 7(4), 1-10. Retrieved from http://dx.doi.org/10.5430/ijba.v7n3p71

Duggan, M., Ellison, N. B., Lampe, C., Lehnhart, A., \& Madden, M. (2015). Social media update 2014. Washington, DC: Pew Internet and Technology. Retrieved from http://www.pewinternet.org/2015/01/09/social-media-update-2014/

Elgort, I., \& Warren, P. (2014). L2 vocabulary learning from reading: Explicit and tacit lexical knowledge and the role of learner and item variables. Language Learning, 64, 365-414. doi: http://dx.doi.org/10.1111/lang.12052

Elley, W., \& Mangubhai, F. (1983). The impact of reading on second language learning. Reading Research Quarterly, 19(1), 53-67. doi: http://dx.doi.org/10.2307/747337

Erdem, A. (2015). A research on reading habits of university students: (Sample of Ankara University and Erciyes University). Procedia- Social and Behavioral Sciences, 174, 3983-3990. Retrieved from http://dx.doi.org/10.1016/j.sbspro.2015.01.1145

Florence, F. O., Adesola, O. A., Alaba, H. B., \& Adewumi, O. M. (2017). A survey on the reading habits among colleges of education students in the information age. Journal of Education and Practice, 8(8), 106-110. Retrieved from http://files.eric.ed.gov/fulltext/EJ1139158.pdf

Goulden, R., Nation, P., \& Read, J. (1990). linguistics, 11(4), 341-363. Retrieved from https://www.victoria.ac.nz/lals/about/staff/publications/paul-nation/1990-GouldenVoc-size.pdf. doi: http://dx.doi.org/10.1093/applin/11.4.341

Grabe, W. (2008). Reading in a second language: Moving from theory to practice. England: Cambridge University Press.

Harji, M. B., Balakrishnan, K., Bhar, S. K., \& Letchumanan, K. (2015). Vocabulary Levels and Size of Malaysian Undergraduates. English Language Teaching, 8(9), 119. doi: http://dx.doi.org/10.5539/elt.v8n9p119

Harl, A.L. (2013). A historical and theoretical review of the literature: Reading and writing connections. In A. S. Horning \& E. W. Kraemer (Eds.), Reconnecting reading and writing (pp. 26-54). Anderson, SC: Parlor Press.

Hopper, R. (2005), What are teenagers reading? Adolescent fiction reading habits and reading choices. Literacy, 39: 113-120. doi: http://dx.doi.org/10.1111/j.14679345.2005.00409.x

Hsueh-Chao, M. H., \& Nation, P. (2000). Unknown vocabulary density and reading comprehension. Reading in a Foreign Language, 13(1), 403-30. Retrieved from http://nflrc.hawaii.edu/rfl/Pastlssues/rfl131 hsuehchao.pdf

Hunt, A., \& Beglar, D. (2005). A framework for developing EFL reading vocabulary. Reading in a foreign language, 17(1), 23.

Iftanti, E. (2012). A survey of the English reading habits of EFL students in Indonesia. TEFLIN Journal, 23(2). Retrieved from http://teflin.org/journal/index.php/journal/article/viewFile/144/136

Ito, F. (2011). L2 Reading-writing correlation in Japanese EFL High School Students. The Language Teacher, 35(5). Retrieved from https://jalt-publications.org/files/pdfarticle/art1_18.pdf

Jacobs, H. L., Zinkgraf, S. A., Wormuth, D. R., Hartfiel, V. F., \& Hughey, J. B. (1981). Testing ESL composition: A practical approach. Rowley, MA: Newbury House. 
Jenkins, J.R., Johnson, E., \& Hileman, J. (2004). When is reading also writing: Sources of individual differences on the new reading performance assessments. Scientific Studies of Reading. 8(2), 25-151. Retrieved from http://dx.doi.org/10.1207/s1532799xssr0802_2

Junco, R. (2011).Too much face and not enough books: The relationship between multiple indices of Facebook use and academic performance. Computers in Human Habits, 28(1), 187-198. Retrieved from http://dx.doi.org/10.1016/j.chb.2011.08.026

Kennedy, A. M., \& Trong, K.L. (2010). Influence of the home literacy environment on reading motivation and reading comprehension. Retrieved from http://www.iea.nl/sites/default/files/irc/IRC2010_Kennedy_Trong.pdf.

Langer, J., \& Flihan, S. (2000). Writing and reading relationships: Constructive tasks. In R. Indrisano \& J. Squire (Eds.), Perspectives on writing: Research, theory, and practice (pp 112-139). Newark, DE: International Reading Association.

Laufer, B., \& Nation, P. (1995). Vocabulary size and use: Lexical richness in L2 written production. Applied linguistics, 16(3), 307-322. Retrieved from http://dx.doi.org/10.1093/applin/16.3.307

Laufer, B., \& Nation, P. (1999). A vocabulary-size test of controlled productive ability. Language testing, 16(1), 33-51. Retrieved from http://dx.doi.org/10.1177/026553229901600103

Laufer, B., \& Goldstein, Z. (2004). Testing vocabulary knowledge: Size, strength, and computer adaptiveness. Language Learning, 54(3), 399-436. doi: http://dx.doi.org/10.1111/j.0023-8333.2004.00260.x

Lee, S. (2014). Korean EFL University Students' English Vocabulary Size and Their Writing Proficiency. 영어교과교육, 13, 21-43. doi:

http://dx.doi.org/10.18649/jkees.2014.13.2.21

Leisure Reading (2014). International Reading Association. Newark, DE: International Reading Association. Retrieved from http://literacyworldwide.org/docs/default-source/where-westand/leisure-reading-position-statement.pdf

Lenhart, A., Purcell, K., Smith, A., \& Zickuhr, K. (2010). Social media \& mobile Internet use among teens and young adults. Pew Internet \& American Life Project. Retrieved from http://files.eric.ed.gov/fulltext/ED525056.pdf

Lim, J. S. Y., Agostinho, S., Harper, B., \& Chicharo, J. (2014). The engagement of social media technologies by undergraduate informatics students for academic purpose in Malaysia. Journal of Information Communication and Ethics in Society, 12(3), 177-194. Retrieved from http://dx.doi.org/10.1108/JICES-03-2014-0016

Liu, Z. (2005). Reading habits in the digital environment: Changes in reading habits over the past ten years. Journal of Documentation, 61(6), pp.700 - 712. Retrieved rom http://dx.dx.doi.org/10.1108/00220410510632040

Loban, W. (1963). The Language of Elementary School Children. Urbana, IL: National Council of Teachers of English.

Maarof, N., Yamat, H., \& Li, K. L. (2011). Role of teacher, peer and teacher-peer feedback in enhancing ESL students' writing. World Applied Sciences Journal, 15, 29-35. Retrieved from http://citeseerx.ist.psu.edu/viewdoc/download?doi=10.1.1.390.1221\&rep=rep1\&type=p df 
Maula, I. (2015). The correlation between students' reading habit and their abilityof writing narrative text (Master's thesis). Retrieved from http://lib.unnes.ac.id/20505/1/2201411051-S.pdf

Meara, P., \& Fitzpatrick, T. (2000). Lex30: An improved method of assessing productive vocabulary in an L2. System, 28(1), 19-30. Retrieved from http://dx.doi.org/10.1016/S0346-251X(99)00058-5

Milton J. (2010). The development of vocabulary breadth across the CEFR levels: A common basis for the elaboration of language syllabuses, curriculum guidelines, examinations, and textbooks across Europe. In Bartning I., Martin M., \& Vedder I. (Eds.), Communicative proficiency and linguistic development: Intersections between SLA and language testing research (pp. 211-232). Eurosla Monograph Series I.

Mohd Ariffin, I. B. (2010). Tabiat Membaca Di Kalangan Pelajar Kemahiran Hidup Di Universiti Pendidikan Sultan Idris (Unpublished Master's thesis). Universiti Pendidikan Sultan Idris: Perak

Morris, L., \& Cobb, T. (2004). Vocabulary profiles as predictors of the academic performance of Teaching English as a Second Language trainees. System, 32(1), 75- 87. Retrieved from http://dx.doi.org/10.1016/j.system.2003.05.001

Mukundan, J., Mahvelati, E. H., Mohd Amin Din, \& Nimehchisalem, V. (2013). Malaysian secondary school students' ESL writing performance in an intensive English program. World Applied Sciences Journal, 22(12), 1677-1684. doi: http://dx.doi.org/10.5829/idosi.wasj.2013.22.12.730

Nicholas, D., Huntington, P., Jamali, H. R., Rowlands, I., Dobrowski, T., \& Tenopir, C. (2008). Viewing and reading habits in a virtual environment: The full- text download and what can be read into it. Aslib Proceedings, 60(3), pp.185-198. Retrieved from http://dx.doi.org/10.1108/00012530810879079

Pandian, A. (2000). A study on readership habits among multi-ethnic, multi-lingual Malaysian students. Paper presented at the Seventh International Literacy and Educational Research Network (LERN) Conference. Retrieved from http://ultibase.rmit.edu.au/Articles/aug01/pandian1.htm

Pandian, A., \& Ibrahim, A. L. (1997). Whither Reading in Malaysia: Confronting Reading Reluctancy Among Pre-University Students. In: Reading in Malaysia. Universiti Kebangsaan Malaysia. Retrieved from https://core.ac.uk/download/pdf/11779029.pdf

Parodi, G. (2007). Reading-writing connections: Discourse oriented research. Reading and Writing, 20, 225-250. Retrieve from https://doi.org/10.1007/s11145-006-9029-7

Pearson, P. D. (2002). Thinking about the reading/writing connection. The Voice. Retrieved from http://www.nwp.org/cs/public/print/resource/329

Perry, K. (2012). What is literacy? -A critical overview of sociocultural perspectives. Journal of Language and Literacy Education [Online], 8(1), 50-71. Retrieved from http://jolle.coe.uga.edu/wp-content/uploads/2012/06/What-is-Literacy_KPerry.pdf

Picton, I. (2014). The Impact of ebooks on the Reading Motivation and Reading Skills of Children and Young People: A rapid literature review, London: National Literacy Trust. Retrieved from http://files.eric.ed.gov/fulltext/ED560635.pdf

Reimer, K. A. (2013). The use of student written weblogs in ESL classes to improve composition (Doctoral dissertation, State University of New York at Fredonia). 
Rosen, L. D., Carrier, L. M., \& Cheever, N. A. (2013). Facebook and texting make me do it: Media-induced task-switching while studying. Computers in Human Habits, 29, 948958. Retrieved from http://dx.doi.org/10.1016/j.chb.2012.12.001

Rowlands, I., Nicholas, D., Williams, P., Huntington, P., Fieldhouse, M., Gunter, B., Withey, R., Jamali, H. R., Dobrowski, T., Tenopir, C. (2008). The Google generation: The information habits of the researcher of the future. Aslib Proceedings, 60(4), pp.290-310. Retrieved from http://dx.dx.doi.org/10.1108/00012530810887953

Sasaki, M. (2000). Toward an empirical model of EFL writing processes: An exploratory study. Journal of second language writing, 9(3), 259-291. Retrieved from http://dx.doi.org/10.1016/S1060-3743(00)00028-X

Shameen, A. (2016). Reading habits and attitudes of UMSKAL undergraduates. International Journal of Applied Linguistics \& English Literature, 5(2), 189- 201. Retrieved from http://dx.doi.org/10.7575/aiac.ijalel.v.5n.2p.189

Shanahan T. (2006). Relations among oral language, reading, and writing development. In M. Charles. A., G. Steve \& F. Jill (Eds.). Handbook of writing research (pp. 171-183). New York, NY: Guilford Press.

Stotsky, S. (1983). Research on Reading/Writing Relationships: A Synthesis and Suggested

Directions. Language Arts, 60(5), 627-642. Retrieved from http://www.jstor.org/stable/41961512

Subashini, A., \& Balakrishnan, M. (2013). Reading habits and attitudes among Malaysian polytechnic students. International Online Journal of educational Science, 5(1), 32-41.

Tseng, W.-T. and Schmitt, N. (2008), Toward a Model of Motivated Vocabulary Learning: A Structural Equation Modeling Approach. Language Learning, 58: 357-400. doi: http://dx.doi.org/10.1111/j.1467-9922.2008.00444.x

Wagner, S. (2002). The reading habits of teams. Journal of Reading Today, 46: 3-4.

Waring, R., \& Nation, I. S. P. (2004). Second language reading and incidental vocabulary learning. Angles on the English speaking world, 4, 97-110.

Wong, A. (2012). An investigation of the predictors of L2 writing among adult ESL students. (Doctoral thesis, University of Canterbury, New Zealand). Retrieved from https://ir.canterbury.ac.nz/bitstream/handle/10092/7837/thesisFullText.pdf? sequenc e=1

Wong, M. S. L. (2005). Language learning strategies and language self-efficacy investigating the relationship in Malaysia. RELC journal, 36(3), 245-269. Retrieved from http://dx.doi.org/10.1177/0033688205060050

Yun, Y. (2005). Factors explaining EFL learners' performance in a timed essay writing test: A structural equation modeling approach (Doctoral dissertation, University of Illinois at Urbana-Champaign).

Zare-ee, A., Hematiyan, N., \& Matin, S. A. (2012). Individualized voiced in undergraduate writing in english as a foreign language. Procedia-Social and Behavioral Sciences, 46, 5782-5786. Retrieved from http://dx.doi.org/10.1016/j.sbspro.2012.06.514

Zickuhr, K., \& Smoth, A. (2012). Digital differences. Washington, DC: Pew Internet and American Life Project. Retrieved from http://pewinternet.org/Reports/2012/Digitaldifferences.aspx 